\title{
Energy management strategies in the oil industry for chemical and thermal environment pollution reduction
}

\author{
Lazăr Avram ${ }^{1}$, Tudora Cristescu ${ }^{1}$, and Monica Emanuela Stoica ${ }^{1, *}$ \\ ${ }^{1}$ Petroleum-Gas University of Ploiesti, Drilling, Extraction and Transport of Hydrocarbons \\ Department, 39 Bucuresti Blvd., Ploiesti, Romania
}

\begin{abstract}
This paper depicts certain thermodynamic processes possibly involved in the oil industry specific activities operation and/or proper equipment maintenance.

On this basis we present a series of courses of action in performing processes like oil storage and transportation, aiming the thermal energy consumption reduction.
\end{abstract}

\section{Introduction}

Chemical pollution reduction, respectively reducing of pollutant emissions, is achieved by reducing fuel consumption. Applying energy management can attain this. For the thermal pollution reduction, energy management is considering the recovery of secondary energy resources, rehabilitation of buildings and equipment.

The ultimate goal of energy management is to maximize energy efficiency, and involves the systematic application of techniques and procedures developed and refined over time. Improving energy efficiency is a strategic objective of the national energy policy, due to the major contribution that makes to the achievement of security of supply, sustainability and competitiveness, to save primary energy resources and reduce emissions of greenhouse gases [1].

An important part of material resources resides in the energy resources. They became notorious after the oil crises that occurred in industrialized countries. Thus, concepts were developed, like renewable energy, alternative energy, energy management and energy efficiency.

Directions implementing energy management strategy address the following issues:

- Technical;

- Organizational;

- No cost, low cost, high cost;

- Psychological component;

- Flowchart.

An activity in a given contour in an organized manner, aims to achieve maximum benefit. Improving energy efficiency is a requirement resulting from this general requirement. Schematically, these issues are as follows:

\footnotetext{
* Corresponding author: monicastoica20022002@yahoo.com
} 


\section{Given contour $\Rightarrow$ an activity in an organized manner $\Rightarrow$ Obtaining maximum benefit $\Rightarrow$ profitable activity $\Rightarrow$ Increasing energy efficiency.}

Energy costs (energy bills) are part of the total costs involved in the smooth conduct of the work performed inside the contour under analysis. Lowering the energy costs contributes to slide of total costs and thus to develop the profits obtained.

\section{Energy expenses $\Downarrow \Rightarrow$ Total expenses $\Downarrow \Rightarrow$ Benefit $\Uparrow$}

Unprofitable activities require minimizing costs. Reduction of expenses involves lowering energy costs.

The concept of energy efficiency has a specific character and content only if it is linked to:

- A well-defined outline;

- An activity that is carried out in an organized manner therein.

The concept of energy efficiency refers to the energy performance involving diminishing the size of energy bills or specific energy expenditure [2].

Increasing energy efficiency in an industrial application requires determination, consistency and professionalism techniques and energy management procedures.

Oversight and improving management activities is done by going through the four stages of the cycle Plan-Do-Check-Act $(\mathrm{P}=$ plan; $\mathrm{D}=$ do, $\mathrm{C}=$ check, $\mathrm{A}=$ act $)$ called "wheel of Deming", shown in Figure 1.

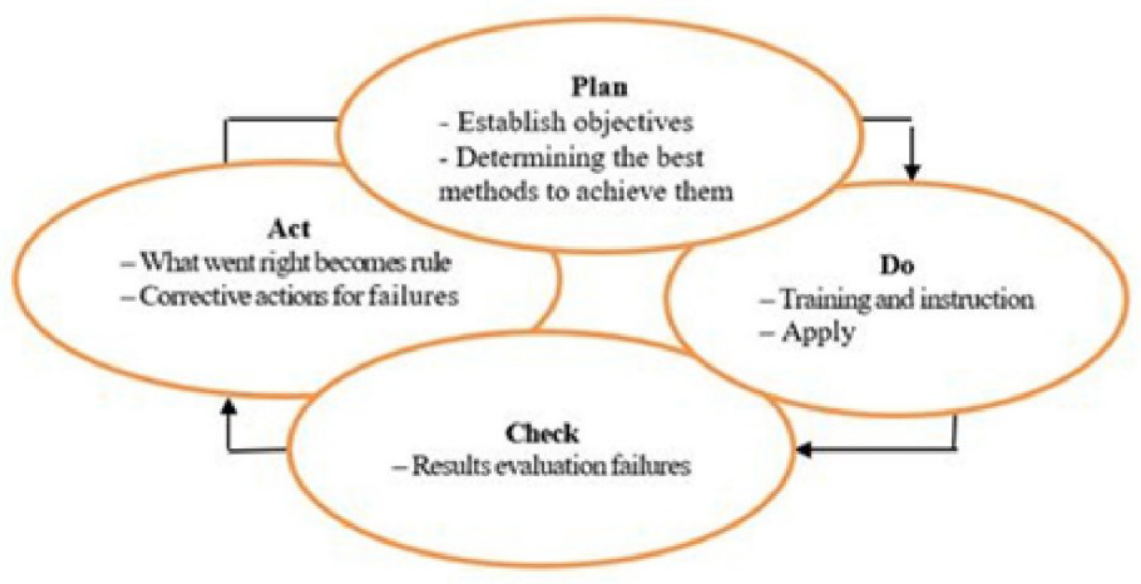

Fig.1. Cycle Plan-Do-Check-Act

Management techniques and procedures aim at: identification;

- allocation;

- $\quad$ harnessing maximum efficiency of material, human and financial resources within an organization.

Energy management procedures involve [3 - 5]:

- $\quad$ in-depth knowledge of specific activity;

- monitoring each of the flows of energy that have entered into and came out of the contour and establishing the links between them.

The activities carried out within the considered contour relate to:

- $\quad$ analysis of energy efficiency in an area;

- $\quad$ staff reaction to the size of energy bills; 
- the operation and effectiveness of the tracking and transmission of information systems on energy consumption within the boundaries given.

Analysis of energy efficiency in a given perimeter begins with an accurate depiction of the qualitative and quantitative matters of energy supply to the activities in the same area:

- determining the nature of energy carriers entering the contour of the balance sheet;

- determining the order of magnitude of consumption for each category of energy carrier;

- determining the payment method for each of them.

The first aspect of the analysis is the size of the energy bill and how it is constituted. Staff reaction to the size of energy bills is another aspect that relates to the attitude in relation to the energy bill; it can fall under one of the following situations:

- $\quad$ energy bills are paid on time without any analysis or internal controls;

- monthly energy bills are compared to readings (records) monthly metering devices mounted at the entrance to the contour of the balance sheet;

- $\quad$ readings (records) are reported monthly to the volume of activity, calculating specific global consumption of energy;

- there is a data acquisition system (not necessarily authomathic), conducting at least weekly monitoring of energy consumption of the major internal and consumers reporting them to their share of the volume of work;

- an automated / computerized monitoring system is implemented and operates continuously evaluating the efficiency of energy utilization, and possibly other material resources usage.

The attitude of the executive management and other personnel regarding the energy usage efficiency is reflected by [3-4]:

- $\quad$ awareness of the importance of the problem;

- $\quad$ the quality and effectiveness of the monitoring system;

- $\quad$ how to capitalize the results obtained;

- the expected reaction from each of the levels of authority to the size and evolution of energy costs.

The third issue is the functioning and effectiveness of information on energy consumption tracking and transmission within the boundaries given.

The analysis includes design, material base and the importance given to system within the organization. The following matters are followed:

- the reading method and frequency of the measuring instruments, especially those that are the basis of measurement, even more those which are the bases for billing;

- the reading transmission method (using templates, through electrical signals or a computer network, etc.);

- $\quad$ information processing module (model algorithm, sizes calculated);

- frequency of writing this report (daily, weekly or monthly) and addressee;

- $\quad$ the impact of reporting and how decisions are made on energy efficiency.

Energy bill reduction requires the commitment of all staff and an effective system for monitoring, processing and capitalizing on data [3-5].

Using secondary energy sources, reusable and renewable recyclable energy sources (RRES), Table 1, together with improving energy efficiency (EEI) can contribute to diminishing energy consumption, ie to reduce greenhouse gas emissions and, consequently, prevent dangerous climate change [6].

Secondary energy resources, Table 2, in a process or aggregate represents all forms of energy used in the process or technological unit. They result from a primary technological process, as by-products thereof, falling within the category of energy loss in the process or unit respectively. Part of the power of secondary energy resources sunk, dissipates in the environment. The causes of secondary energy resources are imperfections of the energy 
processes occurring in the contour considered. When the energy content of secondary energy resources is high, the outline of the processes that occur has a low energy yield [7].

Reusable energy resource is part of the secondary energy resource that can be recovered in terms of economic efficiency. This rate depends on the stage of development of this technology and the costs, at that time, of the energy and materials used [8 - 9].

Table 1. The main categories of renewable energy sources

\begin{tabular}{|l|l|}
\hline \multicolumn{1}{|c|}{$\begin{array}{c}\text { Renewable energy resources } \\
\text { category }\end{array}$} & \multicolumn{1}{|c|}{ Renewable energy resources examples } \\
\hline Wind & Wind with constant speed 6-10 m/s \\
\hline Hydroenergy & Rivers \\
\hline Sun & Solar thermal -electric \\
\hline Biomass & $\begin{array}{l}\text { Biodegradable fraction of products, waste and } \\
\text { residues from agriculture (including plant and } \\
\text { animal substances) forestry and wood } \\
\text { processing, as well as the biodegradable fraction } \\
\text { of industrial and municipal waste. }\end{array}$ \\
\hline Geothermal & Hot springs, geysers \\
\hline Photovoltaic & Solar radiation \\
\hline
\end{tabular}

Table 2. The main categories of secondary energy resources and form of usable energy [6]

\begin{tabular}{|l|l|l|}
\hline $\begin{array}{c}\text { Category of } \\
\text { secondary } \\
\text { energy } \\
\text { resources }\end{array}$ & $\begin{array}{c}\text { Usable energy } \\
\text { form }\end{array}$ & \multicolumn{1}{|c|}{ Secondary energy resources examples } \\
\hline Thermal & $\begin{array}{l}\text { Sensible and/or } \\
\text { latent heat }\end{array}$ & $\begin{array}{l}\text { - Waste gas resulting from pirotechnological } \\
\text { processes from the industries: metallurgical, } \\
\text { chemical, construction materials, burning of } \\
\text { industrial and urban waste; } \\
\text { - Waste hot technology (slag, coke); } \\
\text { - Used steam; } \\
\text { - Moist air discharged from industrial plants } \\
\text { and drying plants }\end{array}$ \\
\hline Combustible & $\begin{array}{l}\text { Chemical } \\
\text { energy }\end{array}$ & $\begin{array}{l}\text { - Waste gas resulting from chemical } \\
\text { processes, furnaces, coke ovens, converters, } \\
\text { refining, coal uplifting; } \\
\text { - Leaching of pulp and paper; } \\
\text { - Waste wood; } \\
\text { - Agricultural waste }\end{array}$ \\
\hline Overpressure & $\begin{array}{l}\text { Potential energy } \\
\text { (overpressure) }\end{array}$ & $\begin{array}{l}\text { - Furnace gas; } \\
\text { - Gases resulting from combustion plants } \\
\text { under pressure; } \\
\text { - Solutions or fluids of technological } \\
\text { aggregates pressure as steam, compressed air }\end{array}$ \\
\hline
\end{tabular}




\section{Case Study}

\subsection{Determination of pollutant emissions}

We considered a firm that produces thermal energy. The company holds four thermal plants that run on natural gas. The main emissions of pollutants discharged from chimneys of combustion installations are $\mathrm{SO}_{2}, \mathrm{NO}_{x}$, particulates and $\mathrm{CO}_{2}$. The determination is based on measurements made with specialised equipment. In our company case periodic analysis is performed regarding the discharged flue gases in the atmosphere.

The amount of pollutants discharged into the atmosphere is determined by relations of the form:

$$
\mathrm{E}=\mathrm{B}^{*} \mathrm{Q}_{\mathrm{i}}{ }^{*} \varepsilon
$$

where: $\mathrm{E}$ is the quantity of pollutants discharged into the atmosphere over a period of time, $[\mathrm{kg}]$; B is the quantity of fuel consumed during that period $[\mathrm{kg}] ; \mathrm{Q}_{i}$ - The lower calorific value of the fuel $[\mathrm{kJ} / \mathrm{kg}] ; \varepsilon$ - Emission factor $[\mathrm{kg} / \mathrm{kJ}]$.

Taking into account the lower calorific value of the fuel gas used relation (1) becomes:

$$
\mathrm{E}=\mathrm{B} * 35815^{*} \varepsilon
$$

The emission factor is the amount of pollutants discharged into the atmosphere per unit of heat introduced with the fuel in the combustion plant. When using several kinds of fuel, the amount of pollutant is determined by summing the amounts calculated for each of them. Emission factors can be determined by calculus or estimate using the specific references [2].

In the case under analysis, the burned gases contain no sulfur or combinations thereof, $\mathrm{SO}_{2}$ emissions are zero. For pollutant $\mathrm{NO}_{\mathrm{x}}$ emission factor, in the case of combustion units with a thermal power of $50 \ldots 100 \mathrm{MW}_{\mathrm{t}}$ [2] and as fuel natural gas is $\varepsilon_{\mathrm{NOx}}=130 \mathrm{~g} / \mathrm{GJ}$ (value corresponding to a boiler load of $100 \%$ ).

Note that in the case studied, the power of the boiler hot water falls under the mentioned levels.

For pollutant $\mathrm{CO} 2$ emission factors are those adopted at present in countries of the European Economic Community; for natural gas is recommended $\varepsilon_{\mathrm{CO} 2}=50000 \mathrm{~g} / \mathrm{GJ}$.

For hot water boilers within thermal power plants belonging to the company analyzed the emissions calculated for an hour are shown in Table 3.

Table 3. Boiler emissions during one hour

\begin{tabular}{|c|c|c|c|c|c|c|}
\hline Emissions & Unit & $\begin{array}{c}\text { BAR } \\
\mathbf{1 7 4 0}\end{array}$ & $\begin{array}{c}\text { BAR } \\
\mathbf{1 9 3 0}\end{array}$ & $\begin{array}{c}\text { HR2 } \\
\mathbf{1 1 0 0}\end{array}$ & $\begin{array}{c}\text { HR2 } \\
\mathbf{1 4 0 0}\end{array}$ & $\begin{array}{c}\text { BAR } \\
\mathbf{1 9 3 0}\end{array}$ \\
\hline $\mathrm{NOx}$ & $\mathrm{kg}$ & 0.20 & 0.24 & 0.47 & 0.38 & 0.43 \\
\hline $\mathrm{CO}_{2}$ & $\mathrm{~kg}$ & 78.08 & 93.71 & 179.83 & 145.77 & 166.58 \\
\hline Total & $\mathrm{kg}$ & 78.28 & 93.95 & 180.29 & 146.15 & 167.01 \\
\hline
\end{tabular}

In Table 4 the corresponding emission values for two consecutive years for each boiler in the analyzed company are mentioned.

In year 2, compared to year 1, there was a decrease in the quantity of emissions; the main reason resides in the diminishing of fuel consumption because of low number of users and applying specific measures on fuel economy. 
Table 4 Thermal plants emissions

\begin{tabular}{|c|c|c|c|c|c|c|c|c|c|}
\hline Emis. & Unit & \multicolumn{2}{|c|}{ CT2 } & \multicolumn{2}{c|}{ CT3 } & \multicolumn{2}{c|}{ CT4 } & \multicolumn{2}{c|}{ CT5 } \\
\hline & & Year 1 & Year 2 & Year 1 & Year 2 & Year 1 & Year 2 & Year 1 & Year 2 \\
\hline 0 & 1 & 2 & 3 & 4 & 5 & 6 & 7 & 8 & 9 \\
\hline & & & & & & & & & 1075.8 \\
$\mathrm{NOx}$ & $\mathrm{kg}$ & 2490.12 & 1912.59 & 973.75 & 742.56 & 957.55 & 404.74 & 1016.66 & 4 \\
\hline $\mathrm{CO}_{2}$ & $\mathrm{~kg}$ & 957739 & 735613 & 374520 & 285600 & 368289 & 155669 & 391023 & 413786 \\
\hline Total & $\mathrm{kg}$ & 960229 & 737526 & 375494 & 286343 & 369247 & 156074 & 392040 & 414862 \\
\hline
\end{tabular}

Table 4 (continuation)

\begin{tabular}{|c|c|c|c|}
\hline Emissions & Unit & \multicolumn{2}{|c|}{ Total } \\
\hline & & Year 1 & Year 2 \\
\hline 10 & 11 & 12 & 13 \\
\hline $\mathrm{NOx}$ & $\mathrm{kg}$ & 5432 & 4161 \\
\hline $\mathrm{CO}_{2}$ & $\mathrm{~kg}$ & 2089348 & 1600311 \\
\hline Total & $\mathrm{kg}$ & 2094780 & 1604472 \\
\hline
\end{tabular}

\subsection{The effect of a habitat thermal insulation on heat dissipation}

Assessment of energy efficient energy performance of buildings and installations is made taking into account climatic parameters [10].

The study proposes estimate of dissipated heat flow, the flow of fuel gas or assessing the amount of $\mathrm{CO} 2$ emitted and the price of fuel used for heating.

The survey is conducted for a flat wall size $4 \times 25 \mathrm{~m}$, built of concrete, insulated on the outside with rigid polystyrene boards and mineral wool inside.

Two cases were considered: non-insulated and insulated walls and two seasons - spring and winter.

It is noted that by isolating a wall, fuel consumption is reduced by approximately $50 \%$ and heating costs will correspondingly decrease. Also, the amount of carbon dioxide emitted into the atmosphere is decreased in proportion to the amount of fuel consumption, from previously very high levels in the case of non-insulated wall, [11-12].

Table 5. Estimated heat flux and flow of fuel gas [12]

\begin{tabular}{|c|c|c|c|c|c|c|c|}
\hline Wall & \multirow{2}{*}{ Season } & $\mathbf{k}$ & $\dot{\boldsymbol{Q}}$ & $\dot{\boldsymbol{V}}_{\boldsymbol{N}}$ & $\dot{\boldsymbol{V}}_{\boldsymbol{N}}$ & $\mathbf{C O}_{2}$ emis. & Fuel cost \\
\cline { 3 - 8 } & $\mathbf{W} /\left(\mathbf{m}^{\mathbf{2}} \mathbf{K}\right)$ & $\mathbf{W}$ & $\boldsymbol{m}_{\boldsymbol{N}}^{\mathbf{3}} / \mathbf{s}$ & $\begin{array}{l}\boldsymbol{m}_{\boldsymbol{N}}^{\mathbf{3}} \\
/ \boldsymbol{m o n t h}\end{array}$ & $\begin{array}{l}\boldsymbol{m}_{\boldsymbol{N}}^{\mathbf{3}} \\
/ \boldsymbol{m o n t h}\end{array}$ & $\begin{array}{c}\mathbf{R O N} / \mathbf{m o n t} \\
\mathbf{h}\end{array}$ \\
\hline \multirow{2}{*}{$\begin{array}{c}\text { Non } \\
\text { insulated }\end{array}$} & winter & 0,5474 & 273,7 & $7,64 \cdot 10^{-6}$ & 20 & 39,26 & 14,47 \\
\cline { 2 - 8 } Insulated & spring & 0,5474 & 54,74 & $1,5 \cdot 10^{-6}$ & 4 & 7,85 & 2,894 \\
\cline { 2 - 8 } & winter & 0,2532 & 126,62 & $3,5375 \cdot 10^{-6}$ & 9 & 17,67 & 6,5115 \\
\hline
\end{tabular}

\section{Conclusions}

In order to increase energy efficiency the following are taken into consideration:

1. The integrated analysis of Contour Energy. 
2. It is necessary to coherently and pragmatically monitor the material and energy flows in the production activities, transport and heat usage.

3. It is recommended to correlate energy costs with the activity carried on in the contour profile analyzed in order to increase competitiveness.

The synthesis of these data characteristic to be known, discussed and compared with similar data and discussed with the personnel involved directly or indirectly in order to establish appropriate ways of improving management activity not only in energy efficiency field but also in other areas.

\section{References}

1. *** Law 121/2014 regarding energy efficiency (Romania, 2014)

2. *** PE 902/86, Normative regarding the making and analysis of energy balance sheets (ICEMENERG, Bucureşti, 1995)

3. A. Badea, A., Bazele termoenergeticii (Ed. Universitatea Politehnica din Bucureşti, Bucuresti, 2003)

4. C. Răducanu, Bilanţuri termoenergetice (Ed. Universitatea Politehnica din Bucureşti, Bucuresti, 2004)

5. *** Monitorul Oficial al Romaniei, 628 (2008)

6. *** apps.upm.ro/cip/docm/m9.pdf, accessed 12.03.2017

7. V. Athanasovici, Resurse energetice secundare - Resurse energetice refolosibile, (Editura Tehnică, Bucureşti, 1989)

8. T. Cristescu, Termotehnica, (Ed. Petroleum - Gas University of Ploiesti, 2009)

9. M. Marinescu, A. Chisacof, P. Răducanu, A. Motorga, Bazele termodinamicii tehnice (Editura Politehnica Press, Bucureşti, 2009)

10. H. Petran, Parametrii climatici necesari determinării performanţei energetice a clădirilor noi şi existente, dimensionării instalațiilor de climatizare a clădirilor şi dimensionării higrotermice a elementelor de anvelopă a clădirilor (Bucuresti, 2011)

11. S. Suditu, M. Pătărlăgeanu, T. Cristescu, Bul. UPG, LVII (2005)

12. T. Cristescu, M. Pătărlăgeanu, S. Suditu, S. Proceedings of the Thermotechnics Conference 2, 74 (2007). 